\title{
The Investigation of Thermodynamics Parameters and Adsorption Kinetic of The Maxilon Blue 5G Dye on Turkey Green Clay
}

\author{
Mehmet Salih NAS ${ }^{1^{*}}$
}

\begin{abstract}
Maxilon Blue 5G dye and Turkey green clay minerals used in adsorption experiments are of great importance recently due to their biological and physicochemical properties. Therefore, kinetic parameters of the adsorption of maxilon blue $5 \mathrm{G}$ dye on green clay were investigated. Studies were performed under adsorption conditions such as $\mathrm{pH}$ (5-11), maxilon blue 5G dye concentration $\left(0.5 \cdot 10^{-6}-2.10^{-5} \mathrm{M}\right)$ and temperature $(298-328 \mathrm{~K})$. Turkey green clay and maxilon blue $5 \mathrm{G}$ dye were characterized by BET, SEM and XRF. The most favorable conditions for the dye adsorption of clay mineral, which is the support substance, were found to be $\mathrm{pH} 11$ and the temperature was $328 \mathrm{~K}$. The kinetic datas obtained from experimental studies were investigated on three different kinetic models such as pseudo-first-order, pseudo-second-order and intraparticle diffusion and it was determined that the adsorption event was carried out more compatible with the second order equation. Thermodynamic functions such as activation enegy (Ea), enthalpy $(\Delta \mathrm{H})$, Gibbs free mechanism $(\Delta \mathrm{G})$ and entropy $(\Delta \mathrm{S})$ were calculated. According to the results obtained from the experimental datas, the interaction between green clay and maxilon blue $5 \mathrm{G}$ are a physical interaction and experimental processes of adsorption are endothermic. These results indicated that green clay can be used as an adsorbent for the adsorption of the maxilon blue $5 \mathrm{G}(\mathrm{MB}-5 \mathrm{G})$.
\end{abstract}

Keywords: Maxilon blue 5G, thermodynamics, green clay, adsorption

\footnotetext{
${ }^{1}$ Mehmet Salih NAS (Orcid ID: 0000-0003-1092-5237), Iğdır Üniversitesi, Mühendislik Fakültesi, Çevre Mühendisliği Bölümü, Iğdır, Türkiye

*Corresponding Author: Mehmet Salih NAS, e-mail: msnas34@gmail.com
} 


\section{INTRODUCTION}

There is a significant amount of synthetic dyestuff in the wastewater of industrial enterprises such as paint, leather, plastic and paper (Chiou et al., 2004). Due to the nature of the paints, it is difficult to remove from waste water. Because the organic acids of the dyes are extremely resistant to heat, light conditions and oxidizing agents (Crini, 2006). Such fluids include a number of contaminating agents, including dissolved solids, toxic, acid or caustic substances and color (Yener et al., 2006). In the case of both volumetric and waste incineration, water pollution caused by the textile industry is more than the whole industry (Singh et al., 2003). Due to the nature of the colors, a very small amount of wastewater is noticeable and undesirable. Therefore it is defined as the first pollutant (Banat et al., 1996). Many methods are used to remove dyestuffs from wastewater, such as chemical oxidation applications, adsorption process, membrane filtration, biodegradation and separation method (Choy et al., 1999). The presence and intensity of the functional groups on the support material surface and the support material in adsorption studies are extremely important for the adsorption capacity (Yenisoy et al., 2004). In order to remove basic and acidic character dyes, alternative materials such as activated carbon, unburned carbon (Choy et al., 1999; Basibuyuk and Forster, 2003; Yenisoy et al., 2004; Wang and Li, 2005), silica material and montmorillonite clay (McKay et al., 1980; Wang et al., 2004), and other adsorbents such as orange fruit shells (Namasivayam et al., 1996), fruit bundle of palm tree (Ho and Mckay, 1998), bark of teak wood, cotton residues, sugar cane powder (McKay et al., 1999; Khattri and Singh, 1999), diatomite (Çalımlı et al., 2018), krill clay (Nas et al., 2017), polymer composite Films (Şen et al., 2018), Graphene Oxide-Chitosan (Savk et al., 2018a), Novel Chitosan-Based Nanocomposites (Savk et al., 2018b), Turkish
Green Clay (Demirbaş et al., 2016) were utilized in many studies.

The characteristic of support material used in the process is extremely important (Ali, 2012; Ali et al., 2012) for the efficiency of adsorption studies. Due to its high surface area and adsorption capacity, activated carbon is the most preferred support material for adsorption studies (Ali, 2010; Auta and Hameed, 2011; Ali et al., 2012). But activated carbon is a very expensive support material despite its excellent adsorption capacity (Auta and Hameed, 2012). Clay minerals are inexpensive, suitable for ecosystems, and have simple-to-use properties (Rehman et al., 2013). In adsorption processes, the graphene-carbon nanotube composite is used extensively to remove methylene blue from the wastewater (Wang et al., 2014). In this study, the clay which is considered as a support agent for dye removing is really green. In the literature studies, green clay is an organic composite mineral composed of decomposed plant based wastes as seaweed and iron compounds and the illite, known as the French green clay for centuries, took this name from the rock quarries on the southern slopes of France. It has been evaluated in different areas such as medicine cleaning and detox. Recently, it has been found that green clay mineral has a curative effect on patients with ulcers (Williams et al., 2008; Anonymous, 2016). Williams et al. (2008) have found that clay minerals can provide an inexpensive treatment for skin infections due to the antibacterial properties of clay minerals. The green clay used in this study was obtained from the mineral rock beds in the Gürpinar district of Van. For this reason, the name was considered as Turkish green clay. The aim of this study was to investigate the adsorption kinetics of maxilon blue 5G on the Turkish green clay (TGC) under a series of physicochemical conditions. For adsorption characterization, it was detected with SEM (Scanning Electron Microscope) and BET (Brunauer, Emmet ve Teller) devices. In this 
study, important parameters such as contact time, $\mathrm{pH}$ and temperature were investigated during the experiment. In addition, thermodynamic functions such as entropy, enthalpy and Gibbs free energy were examined.

\section{MATERIALS AND METHODS}

\section{Materials}

Clay mineral used in this study was obtained from the Gürpınar districts of Van and the characterization of the samples was evaluated. To determine the surface area and pore volume of TGC clay mineral, BET (micromeritics FlowSorb 11-2300) apparatus was used. The surface morphology of the samples used for the adsorption was determined with the SEM apparatus. MB-5G was obtained from Setas, Textile Co. (Bursa, Turkey). The chemical used in the study was analytical grade and the water used was evaluated by precision distillation in millimetric quality. The chemical composition and specific surface area of the Turkey green clay are shown in Table 1 and Table 2.

Table 1. Chemical composition of Turkey Green Clay

\begin{tabular}{lc}
\hline Constituent & Percentage present (\%) \\
\hline $\mathrm{Mg}$ & 20,74 \\
$\mathrm{Al}$ & 9,20 \\
$\mathrm{Si}$ & 44,79 \\
$\mathrm{Fe}$ & 12,48 \\
$\mathrm{Ca}$ & 10,02 \\
Others & 2,77 \\
\hline
\end{tabular}

Table 2. Some properties of Green Clay

\begin{tabular}{ll}
\hline Constituent & Values \\
\hline Particle size (mesh) & 325 \\
$\mathrm{pH}$ & 9.23 \\
Specific surface areas $\mathrm{m}^{2} / \mathrm{g}$ & \\
Single point specific surface area & $1.484 \mathrm{e}+01 \mathrm{~m}^{2} / \mathrm{g}$ \\
Multipoint specific surface areas & $1.547 \mathrm{e}+01 \mathrm{~m}^{2} / \mathrm{g}$ \\
\hline
\end{tabular}

\section{Experimental procedure}

Adsorption studies were performed using mechanical mixer in the balloon glass. All colorant solution was prepared with ultra-pure water. The kinetic assays were carried out at a constant agitation rate of $600 \mathrm{rpm}$, at a concentration of $1.10^{-5} \mathrm{M}$ dyestuff, under conditions of $\mathrm{pH} 7$ and $298 \mathrm{~K}$. As a result of preliminary studies, the dye concentration was $5.10^{-6} \mathrm{~mol} / \mathrm{L}, 1.10^{-5} \mathrm{M}$ and $2.10^{-5} \mathrm{M}$, and the effect of $\mathrm{pH}$ on the Turkey green clay of the dyestuff was analyzed from $\mathrm{pH} 5$ to 11 . The $\mathrm{pH}$ of the dyestuff solutions was adjusted by $\mathrm{pH}$ electrode from $0.05 \mathrm{~N} \mathrm{NaOH}$ and $0.05 \mathrm{~N} \mathrm{HCl}$ solutions. The effect of temperature on the adsorption studies was carried out at, $298 \mathrm{~K}, 308$ $\mathrm{K}, 318 \mathrm{~K}$ and $328 \mathrm{~K} .5$ milliliters of sample were taken at a certain time interval and the samples were centrifuged at $3500 \mathrm{rpm}$ for 6 minutes, and the UV-Vis spectrophotometer (Cary 1E UV-Vis spectrophotometer, Varian) was used to monitor the maximum absorbance wavelength changes of the obtained supernatant. The adsorbed amount of dyestuff at any time $\mathrm{t}, \mathrm{q}_{\mathrm{t}}$, was calculated from the mass balance equation 1 .

$\mathrm{q}_{\mathrm{t}}=(\mathrm{Co}-\mathrm{Ct}) \mathrm{V} / \mathrm{m}$ 
In the equation given herein, $\mathrm{Co}$ and $\mathrm{Ct}$ expressions indicate the concentration value at first and at any time. $V$ and $m$ denote the volume of the dye used and the mass of the green clay mineral (Alkan et al., 2008).

\section{RESULTS AND DISCUSSION}

The effect of contact and equilibrium times and dye concentration factor
Adsorption effect on TGC of maxilon blue $5 \mathrm{G}$ was studied at constant conditions such as a stirring time of $600 \mathrm{rpm}$, a specific contact time and $\mathrm{pH}$ 7. From Table 3, it was found that the amount of adsorbed maxilon blue $5 \mathrm{G}$ increased from 0.195 to $0.752 \mathrm{mmol} \mathrm{g}^{-1}$ for an increase of $0.5 \times 10^{-5} \mathrm{M}$ to $2.0 \times 10^{-5} \mathrm{M}$ at the initial maxilon blue $5 \mathrm{G}$ concentration. The time required to reach this concentration is about 60 minutes.

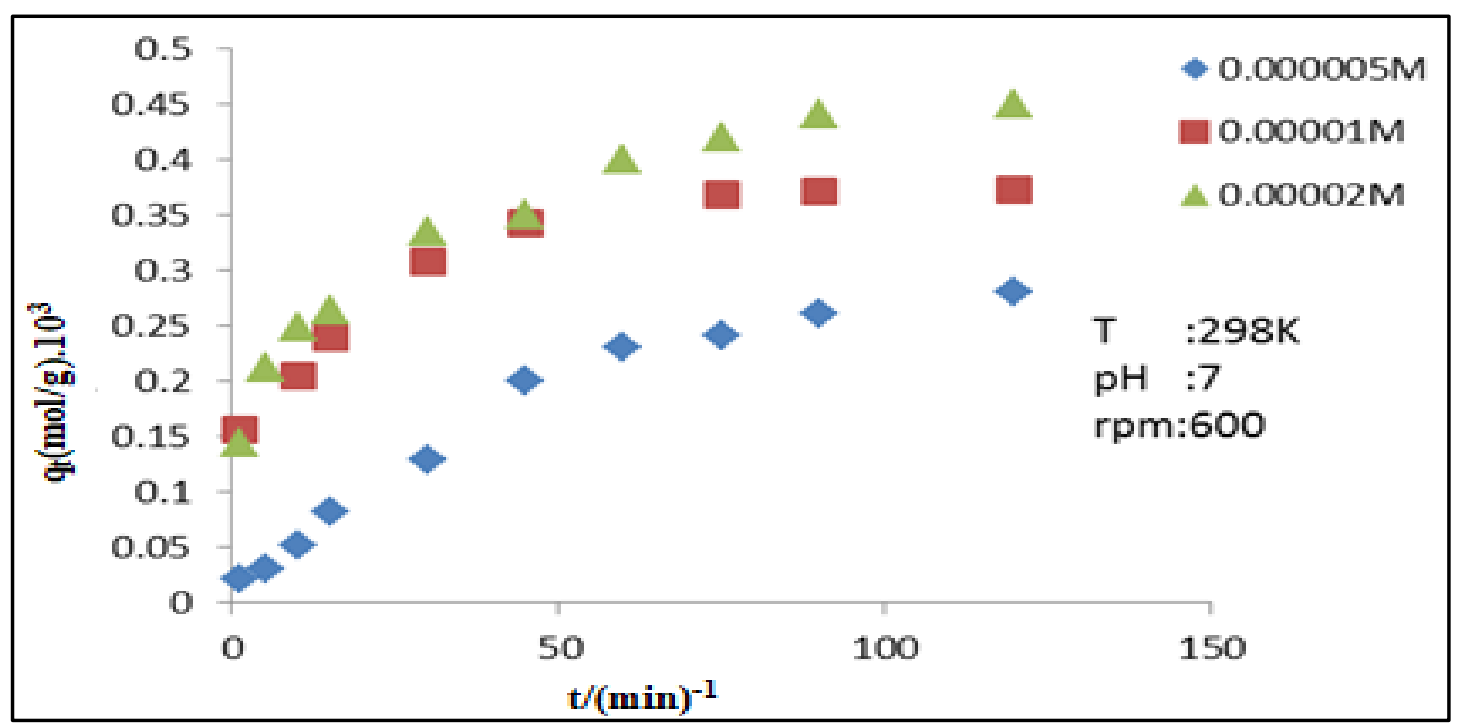

Figure.1. The effect of dyestuff concentration

\section{Effect of solution pH and temperature}

The adsorbent surfaces used in the adsorption studies have generally a negative and positive charge. The ions on these surfaces are affected because they are very sensitive to $\mathrm{pH}$ changes. In some cases, the net surface charge of the support material is zero. The $\mathrm{pH}$ value of the adsorbent considered for the support material is shown as pHpzc (the point of zero charge) where the net surface charge is zero (neutral) (Wang et al., 2014). Figure $2 \mathrm{a}$ shows the effect of changing the $\mathrm{pH}$ of 5 to 11 in $\mathrm{MB}-5 \mathrm{G}$ aqueous solutions under constant conditions such as temperature, initial dye concentration and clay amount. When Figure 2 is examined, the adsorbent ( $\mathrm{g}$ ) adsorbed per unit mass ( $\mathrm{mmol}$ ) is increased when the $\mathrm{pH}$ is increased from 5 to 11 .
This can be explained by the electrostatic attraction between the positively charged MB$5 \mathrm{G}$ and the negatively charged clay surface. One of the most important factors in adsorption studies is the temperature factor. In this study, adsorption kinetics of MB-5G on TGC clay mineral at 298, 308, 318 and $328 \mathrm{~K}$ temperature were investigated under initial $\mathrm{MB}-5 \mathrm{G}$ concentration conditions at $2.0 \times 10^{-5} \mathrm{M}$ at $\mathrm{pH} 7$. The results showed that the increase in temperature showed that MB-5G increased the amount of adsorption on the clay mineral (Alkan et al., 2008; Nandi et al., 2009; Ghaedi et al., 2011) and the maximum adsorption capacity of MB-5G adsorbed onto the surface of TGC was determined at $328 \mathrm{~K}$. In the results, we can say that the adsorption process is endothermic. 

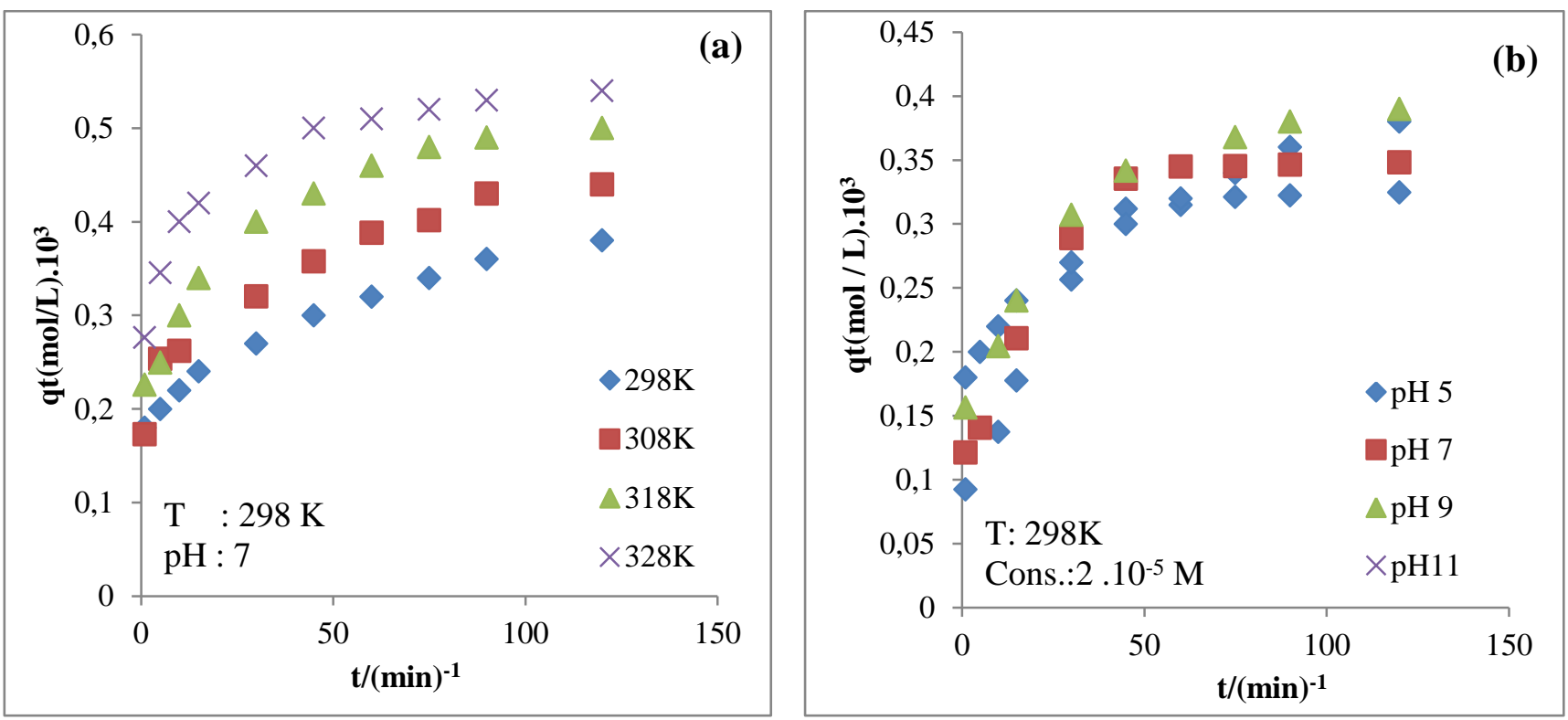

Figure 2. The effect of solution of $\mathrm{pH}(\mathrm{a})$ and temperature(b) to the adsorption rate of $\mathrm{MB}-5 \mathrm{G}$ on TGC

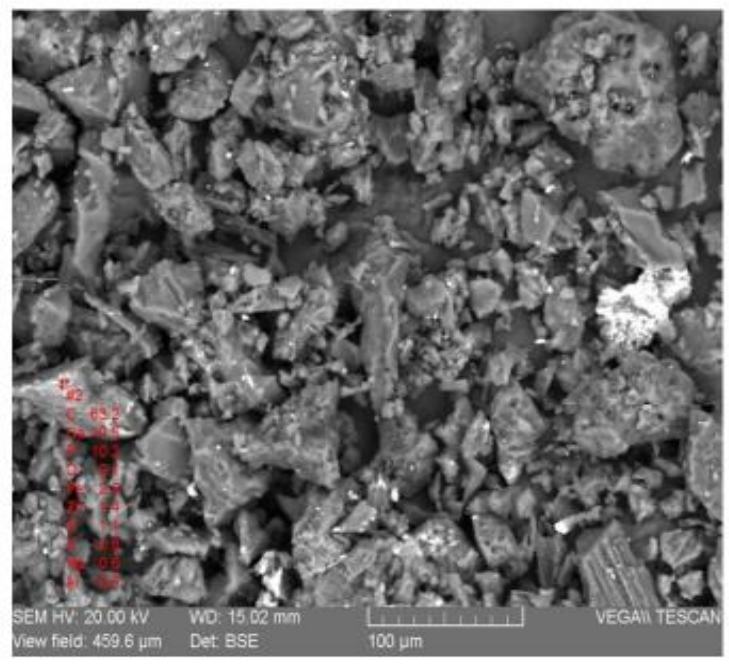

(a)

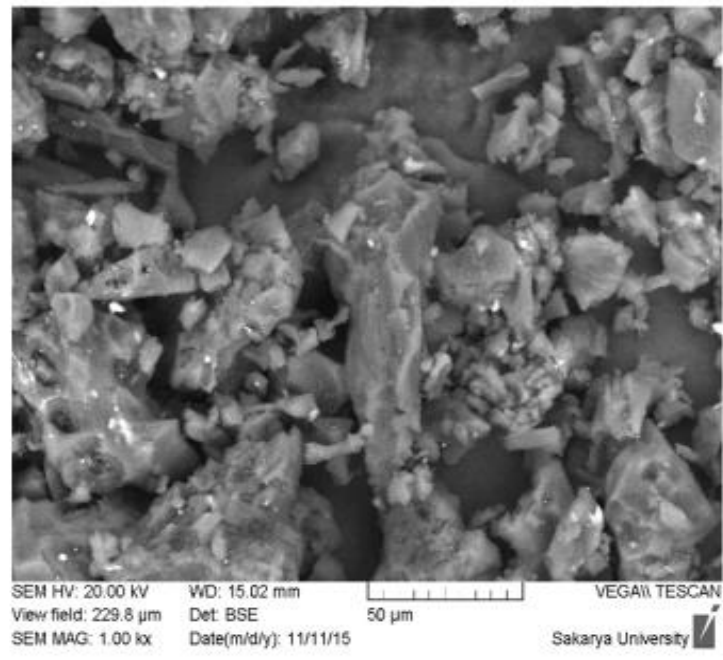

(b)

Figure 3. SEM microphotographs of (a) TGC, (b) MB-5G adsorbed by TGC after $120 \mathrm{~min}$

\section{Investigation of figures SEM}

SEM images of Turkey green clay material (TGC) and the composite (TGC/MB-5G) consisted of pure maxilon blue $5 \mathrm{G}$ - green clay are given in Figure 3. Figure 3a shows SEM image of TGC. Some pores which have been formed because of air are seen on the surface.
Figure $3 b$ shows surface of composite (TGC/MB-5G). Bright and dark dots are seen on the surface of composite (TGC/MB-5G). These dots show both MB-5G and green clay. The surface of the adsorption agent appears brighter and smoother. This indicates that the material considered as support is coated with MB-5G. 
Table 3. Kinetic datas calculated for adsorption

\begin{tabular}{|c|c|c|c|c|c|c|c|c|c|c|}
\hline \multicolumn{5}{|c|}{ Parameters } & \multicolumn{6}{|c|}{ Pseudo-second-order } \\
\hline $\mathbf{T} / \mathbf{K}$ & $\begin{array}{l}\text { Con. } \\
\text { mol. } \mathbf{L}^{-1} \\
1^{-5}\end{array}$ & $\mathbf{p H}$ & $\begin{array}{c}\text { Stir. Speed } \\
\text { rpm }\end{array}$ & $\begin{array}{c}\text { Pseudo } \\
\text { order } \mathbf{R}^{2}\end{array}$ & $\begin{array}{c}\text { qe }_{\text {ecal. }} \text { ) } \\
\text { first- } \\
\mathbf{g}^{-1}\end{array}$ & $\begin{array}{c}\text { qe(exp.) } \\
\text { mg. } \\
\mathbf{g}^{-1}\end{array}$ & $\begin{array}{c}\mathrm{k}_{2}(\mathrm{~g}) \\
\mathrm{mg} \cdot \\
\text { min }^{-1}\end{array}$ & $\mathbf{R}^{2}$ & $\begin{array}{c}\mathbf{h}(\mathbf{m o l}) \\
\underset{\mathbf{g}^{-1}}{ }\end{array}$ & $\mathbf{t}$ \\
\hline 298 & 0.2 & 7 & 600 & 0.92 & 0.39 & 0.40 & 0.362 & 0.99 & 0.140 & 6.06 \\
\hline 308 & 0.2 & 7 & 600 & 0.9 & 0.42 & 0.44 & 0.420 & 0.99 & 0.160 & 5.03 \\
\hline 318 & 0.2 & 7 & 600 & 0.94 & 0.49 & 0.50 & 0.491 & 0.99 & 0.195 & 4.12 \\
\hline 328 & 0.2 & 7 & 600 & 0.98 & 0.50 & 0.49 & 0.637 & 0.99 & 0.383 & 2.41 \\
\hline 298 & 0.05 & 7 & 600 & 0.94 & 0.19 & 0.20 & 0.322 & 0.98 & 0.068 & 9.7 \\
\hline 298 & 0.1 & 7 & 600 & 0.96 & 0.39 & 0.40 & 0.362 & 0.99 & 0.140 & 6.06 \\
\hline 298 & 0.2 & 7 & 600 & 0.85 & 0.54 & 0.57 & 0.106 & 0.96 & 0.066 & 12.5 \\
\hline 298 & 0.2 & 5 & 600 & 0.97 & 0.36 & 0.38 & 0.423 & 0.98 & 0.156 & 5.46 \\
\hline 298 & 0.2 & 7 & 600 & 0.93 & 0.38 & 0.39 & 0.916 & 0.99 & 0.335 & 3.14 \\
\hline 298 & 0.2 & 9 & 600 & 0.98 & 0.39 & 0.40 & 0.362 & 0.99 & 0.140 & 6.06 \\
\hline 298 & 0.2 & 11 & 600 & 0.97 & 0.39 & 0.41 & 0.368 & 0.99 & 0.144 & 6.13 \\
\hline
\end{tabular}

\section{Adsorption study kinetics}

In order to understand the control mechanism in sorption studies. It is stated with experimental model which model is carried out with experimental datas. The pseudo first-order equation is generally expressed as follows (Lagergren, 1898; Weber et al., 1963; Hunter, 1999).

$\ln \left(q_{e^{-}} q_{t}\right)=\ln q_{e}-k_{i t}$

herein, the pseudo-first-order velocity constant is $\mathrm{k}_{1}$. The datas are indicated in Table 3 .

\section{Pseudo - second - order equation}

If the adsorption process is carried out by a second order mechanism, The so-called-second equation 3 is indicated below (Ho and McKay, 1998)

$\frac{t}{q e}=\frac{1}{k_{2} q_{e}^{2}}+\frac{1}{q_{e}} t$

The initial adsorption rate (h) is expressed by equation 4.

$h=k_{2} q_{e}$

herein, when we look $\mathrm{k}_{2}$ and $\mathrm{k}_{1}$ values in Table 3 , it is understood that the adsorption mechanism is carried out by second order kinetic equations.
The initial ratio of intra-particle diffusion was obtained by the following equation 5 (Doğan et al., 2006).

$\left.q_{t}=k_{\text {int. }} t_{1 / 2}+C\right)$

Herein, $\mathrm{k}_{\mathrm{int}}$ is the intraparticle diffusion rate constant $\left(\mathrm{mg}(\mathrm{g} \mathrm{min})^{-1 / 2}\right)^{-1}$ and is given in Table 4.

\section{Thermodynamic parameters}

In order to calculate the activation energy of the adsorbed MB-5G dyestuff on the support material in the study, arrhenius equation 6 was used.

$$
\ln k_{2}=\ln A-\frac{E a}{R g \cdot T}
$$

In the aforementioned equation, $\mathrm{Ea}, \mathrm{k}_{2}$ and A expressions respectively indicate the activation energy ( $\mathrm{J} / \mathrm{mol}$ ), the rate constant ( $\mathrm{g} /$ mol s) of the sorption and the Arrhenius factor. In order to calculate the Ea value, the Ea value of lnk versus 1 / $\mathrm{T}$ was found to be 11.8. From the activation energy, we can say that the working process is carried out under the conditions of physical adsorption (Laidler and Meiser, 1999). In the Eyring equation 7, the most important function values of thermodynamics such as entropy $(\Delta \mathrm{S})$, enthalpy $(\Delta \mathrm{H})$ and free Gibbs energy $(\Delta \mathrm{G})$ were obtained (Singh, 2000). 
Table 4. Intra - particle diffusion data from adsorption studies

\begin{tabular}{|c|c|c|c|c|c|c|c|}
\hline \multicolumn{4}{|c|}{ Mass transfer } & \multicolumn{4}{|c|}{ Intra - particle diffusion } \\
\hline $\mathbf{T} / \mathbf{K}$ & $\begin{array}{c}\text { Conc. } \\
\text { mol. } \mathbf{L}^{-1} \cdot 10^{-5}\end{array}$ & pH & $\begin{array}{c}\text { Stirring } \\
\text { Speed }(\mathbf{r p m})\end{array}$ & $\underset{\min ^{-1 / 2}}{\operatorname{kint}_{1} \text { mg.g }^{-1}}$ & $\mathbf{R}_{1}{ }^{2}$ & $\underset{\min ^{-1 / 2}}{\text { kint. }_{.2} \text { mg.g }^{-1}}$ & $\mathbf{R}_{2}^{2}$ \\
\hline 298 & 0.2 & 7 & 600 & 0.003 & 0.95 & 0.012 & 0.98 \\
\hline 308 & 0.2 & 7 & 600 & 0.023 & 0.98 & 0.093 & 0.94 \\
\hline 318 & 0.2 & 7 & 600 & 0.044 & 0.97 & 0.0016 & 0.97 \\
\hline 328 & 0.2 & 7 & 600 & 0.064 & 0.98 & 0.0056 & 0.78 \\
\hline 298 & 0.05 & 7 & 600 & 0.024 & 0.96 & 0.004 & 0.92 \\
\hline 298 & 0.1 & 7 & 600 & 0.003 & 0.95 & 0.012 & 0.98 \\
\hline 298 & 0.2 & 7 & 600 & 0.041 & 0.98 & 0.0045 & 0.69 \\
\hline 298 & 0.2 & 5 & 600 & 0.033 & 0.94 & 0.0011 & 0.99 \\
\hline 298 & 0.2 & 9 & 600 & 0.035 & 0.98 & 0.0016 & 0.96 \\
\hline 298 & 0.2 & 7 & 600 & 0.003 & 0.95 & 0.0012 & 0.98 \\
\hline 298 & 0.2 & 11 & 600 & 0.0024 & 0.97 & 0.0027 & 0.95 \\
\hline
\end{tabular}

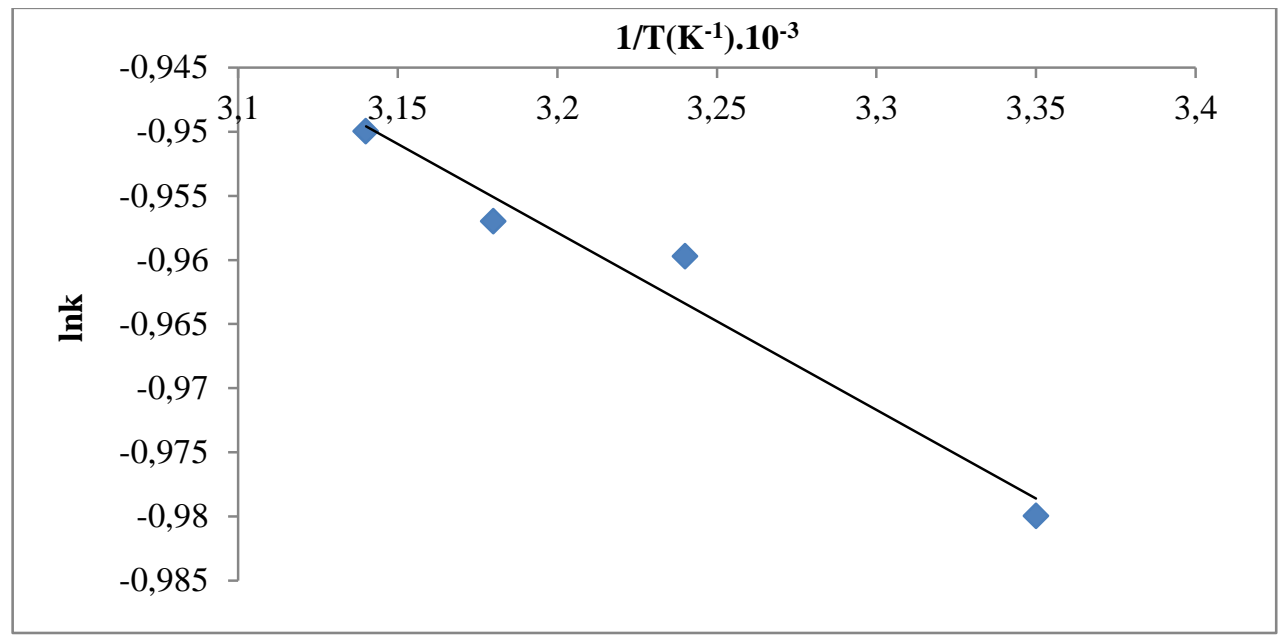

Figure 4. Arrhenius graph for adsorption of MB-5G in TGC.

$\ln \left(k_{2} / T\right)=\ln (k b / h)+\frac{\Delta S}{R g}-\frac{\Delta H}{R g T}$

In the above equation, the expressions $\mathrm{kb}$ and $\mathrm{h}$ denote Boltzmann $\left(1.3807 .10^{-23} \mathrm{~J} / \mathrm{K}\right.$ and Planck $\left(6.6261 .10^{-34} \mathrm{~J} \mathrm{~s}\right)$ constants. The value of Standard enthalpy change was also found to be $15.2 \mathrm{k} . \mathrm{J} / \mathrm{mol}$. This indicates that the event is endothermic. The small amount of enthalpy change indicates a loose bond between the adsorbate molecules and the support surface (Mall and Upadhyay, 1995).

Table 5. Thermodynamic function datas obtained by adsorption of TGC surface with MB-5G

\begin{tabular}{lcccc}
\hline Parameter & & & & \\
\hline T/K & $\Delta \mathbf{G ~ ( k J / m o l )}$ & Ea $(\mathbf{k J} / \mathbf{m o l})$ & $\Delta \mathbf{H ~ ( k J / m o l )}$ & $\Delta \mathbf{S ~ ( j / K . m o l )}$ \\
\hline $\mathbf{2 9 8}$ & 64.96 & & & \\
$\mathbf{3 0 8}$ & 66.63 & 11.8 & 15.2 & -167.3 \\
$\mathbf{3 1 8}$ & 68.3 & & & \\
$\mathbf{3 2 8}$ & 69.97 & & & \\
\hline
\end{tabular}




\section{CONCLUSION}

Herein, we showed that Turkey green clay (TGC) can be used as a good support material for the adsortion of $\mathrm{MB}-5 \mathrm{G}$. MB-5G concentration, temperature, $\mathrm{pH}$ and contact time were taken as kinetic parameters in the adsorption process. The amount of adsorption increased with the increase $\mathrm{pH}$ and temperature values. The experiments results showed the adsorption process are compatiple with the second order kinetic model. The positive value of Gibbs energy showed the adsorption process are not spontaneous, and the adsortion process are endothermic due to the small and positive value of enthalpy. The small enthalpy change indicates forming of a loose bond between the a MB-5G molecules and the support surface. The selected Turkey Green Clay as a carrier for the adsortion process has a high adsortion potentional because of an effective adsortion effect in aqueous medium.

\section{REFERENCES}

Ali I, 2010. The quest for active carbon adsorbent substitutes: Inexpensive adsorbents for toxic metal ions removal from wastewater. Separation and Purification Reviews 39(3):95-171.

Ali I, Asim M, Khan TA, 2012. Low cost adsorbents for removal of organic pollutants from wastewater. Journal of Environmental Management 113C:170-183.

Ali I, 2012. New generation adsorbents for water treatment. Chemical Reviews 112(10):50735091.

Alkan M, Doğan M, Turhan Y, Demirbaş Ö, Turan $\mathrm{P}, 2008$. Adsorption kinetics and mechanism of maxilon Blue $5 \mathrm{G}$ dye on sepiolite from aqueous solutions. The Chemical Engineering Journal 139(2):213-223.
Auta M, Hameed BH, 2012. Acid modified local clay beads as effective low-cost adsorbent for dynamic. adsorption of methylene blue. Journal of Industrial and Engineering Chemistry 19(4):1153-1161.

Auta M, Hameed BH, 2011. Preparation of waste tea activated carbon using potassium acetate as an activating agent for adsorption of acid blue 25 dye. The Chemical Engineering Journal 171(2):502-509.

Auta V, Hameed BH, 2012. Modified mesoporous clay adsorbent for adsorption isotherm and kinetics of methylene blue. The Chemical Engineering Journal s 198-199:219-227.

Anonymous, 2016. https://www.leaf.tv/articles/greenclaybenefits/. (07.12.2016)

Banat IM, Nigam P, Singh D, Marchant R, 1996. Microbial decolorization of textile-dyecontaining effluents: A review. Bioresource Technology 58(3):217-227.

Basibuyuk M, Forster CF, 2003. An examination of the adsorption characteristics of a basic dye (Maxilon Red BL-N) on to live activated sludge system. Process Biochem, (38): 1311-1316.

Chiou MS, Ho PY, Li HY, 2004. Adsorption of anionic dyes in acid solutions using chemically cross-linked chitosan beads. Dyes and Pigments 60(1):69-84.

Choy KKH, McKay G, Porter JF, 1999. Sorption of acid dyes from effluents using activated carbon. Resource Conservation Research, 27, 57-71.

Crini G, 2006. Non-conventional low-cost adsorbents for dye removal: A review. Bioresource Technology 97(9):1061-1085.

Çalımlı MH, Demirbaş Ö, Aygün A, Alma MH, Nas MS, Şen F, 2018. Immobilization kinetics and mechanism of bovine serum albumin on diatomite clay from aqueous solutions. Applied Water Science, 8:209. Doi: 10.1007/s13201-018-0858-8. 
Demirbaş Ö, Nas MS, 2016. Kinetics and mechanism of the adsorption of methylene blue from aqueous solution onto turkish green clay. Archives of Current Research International, 6(3): 1-10.

Doğan M, Alkan M, Demirbaş Ö, Özdemir Y, Özmetin C, 2006. Adsorption kinetics of Maxilon Blue GRL onto sepiolite from aqueous solutions. The Chemical Engineering Journal 124(1-3):89-101.

Ghaedi M, Hossainian H, Montazerozohori M, Shokrollahi A, Shojaipour F, Soylak M, Purkait MK, 2011. A novel acorn based adsorbent for the removal of brilliant green. Desalination 281:226-233.

Ho YS, Mckay G. 1998. Sorption of dye from aqueous solution by peat. Chem. Eng. J, 70(2):115-124.

Hunter RJ, 1999. Introduction to modern colloid science. Oxford University Press. New York. USA.

Khattri SD, Singh MK, 1999. Colour removal from dye wastewater using sugar cane dust as an adsorbent. Adsorption Science \& Technology, 17(4):269-282.

Lagergren S, 1898. About the theory of so called adsorption of soluble substances. Kungliga Svenska Vetenskapsakademiens Handlingar, 24, 1-39, 1898.

Laidler KJ, Meiser JM, 1999. Physical Chemistry. Houghton Mifflin. p.852. New York-ABD

Mall ID, Upadhyay SN, 1995. Treatment of methyl violet bearing wastewater from paper mill effluent using low cost adsorbents. J.Indian Pulp Paper Technol. Assoc, 7(1): 51-57.

McKay G, Otterburn MS, Sweeney AG, 1980. The removal of colour from effluent using various adsorbents-III. Silica: Rate processes. Water Research (14): 15-20.

McKay G, Porter JF, Prasad GR, 1999. The removal of dye colours from aqueous solutions by adsorption on low-cost materials. Water, Air and Soil Pollution, 114(3-4): 423-438.
Namasivayam C, Muniasamy N, Gayatri K, Rani M, Ranganathan K, 1996. Removal of dyes from aqueous solutions by cellulosic waste orange peel. Bioresource Technology 57(1):37-43.

Nandi BK, Goswami A, Purkait MK, 2009. Adsorption characteristics of brilliant green dye on kaolin. Journal of Hazardous Materials, (161):387-395.

Nas MS, Gür A, Gür T, Yönten V, 2017. Exploring thermodynamics and kinetic parameters of immobilized catalase enzyme via adsorption on krill clay. Desalination and Water Treatment (67): 178-186.

Rehman MSU, Munir M, Ashfaq M, Rashid N, Nazar MF, Danish M, Han JI, 2013. Adsorption of brilliant green dye from aqueous solution onto red clay. Chemical Engineering Journal (228): 54-62.

Savk A, Sen B, Demirkan B. Kuyuldar E, Aygun A, Nas MS, Sen F, 2018a. Graphene oxidechitosan furnished monodisperse platinum nanoparticles as importantly competent and reusable nanosorbents for methylene blue removal. Chitosan-Based Adsorbents for Wastewater Treatment. Materials Research Forum LLC. USA. 24 pages. DOI: http://dx.doi.org/10.21741/978194529175311.

Savk A, Sen B, Demirkan B, Kuyuldar E, Aygun A, Nas MS, Sen F, 2018b. Novel ChitosanBased Nanocomposites for Dye Removal Applications. Chitosan-based adsorbents for wastewater treatment. Materials Research Forum LLC. USA. 24 DOI: http://dx.doi.org/10.21741/97819452917533.

Singh D, 2000. Studies of the adsorption thermodynamics of oxamyl on fly ash. Adsorption Science\&Technology 18(8): 741-748. 
Singh KP, Mohan D, Sinha. S, Tondon GS, Gosh D, 2003. Color removal from wastewater using low-cost activated carbon derived from agricultural waste material. Ind. Eng. Chem. Res (42):1965-1976.

Şen F, Demirbaş Ö. Çalımlı MH, Aygün A, Alma MH, Nas MS, 2018. Dye removal from aqueous solution using polymer composite films. Applied Water Science 8:206.

Wang CC, Juang LC, Hsu TC, Lee CK, Lee JF, Huang FC, 2004. Adsorption of basic dyes onto montmorillonite. Journal of Colloid and Interface Science (273): 80-86.

Wang P, Cao M, Wang C, Ao Y, Hou J, Qian J, 2014. Kinetics and thermodynamics of adsorption of methylene blue by a magnetic graphene-carbon nanotube composite. Applied Surface Science (290): 116-124.

Wang S, Li H. 2005. Dye adsorption on unburned carbon: Kinetics and equilibrium. Journal of Hazardous Materials, 126(1-3): 71-77.
Weber WJ, Morris JC, 1963. Kinetics of adsorption on carbon from solution. Journal of Sanitary Engineering Division ASCE, (18): 31-42.

Williams LB, Haydel SE, Giese Jr RF, Eberl DD, 2008. Chemical and mineralogical characteristics of French green clays used for healing. Clays Clay Miner, 56(4):437-452.

Yener J, Kopac T, Dogu G, Dogu T, 2006. Adsorption of Basic Yellow 28 from aqueous solutions with clinoptilolite and amberlite. Journal of Colloid and Interface Science (294): 255-264.

Yenisoy-Karakaş S, Aygün A, Güneş $\mathrm{M}$, Tahtasakal E, 2004. Physical and chemical characteristics of polymer-based spherical activated carbon and its ability to adsorb organics, Carbon (42): 477-484. 